\title{
Review
}

\section{Th17 Cells}

\section{Biology, Pathogenesis of Autoimmune and Inflammatory Diseases, and Therapeutic Strategies}

\author{
Mohan S. Maddur, ${ }^{\star \dagger \ddagger}$ Pierre Miossec, ${ }^{\S}$ \\ Srini V. Kaveri, ${ }^{* \dagger \uparrow}$ and Jagadeesh Bayry ${ }^{* \dagger \uparrow \uparrow}$ \\ From INSERM,* Paris; the Cordelier Research Center, ${ }^{\dagger}$ University \\ of Pierre and Marie Curie, Paris; the University of Paris \\ Descartes, ${ }^{\ddagger}$ Paris; the Immunogenomics and Inflammation \\ Research Unit, ${ }^{\S}$ Department of Clinical Immunology and \\ Rheumatology, Edouard Herriot Hospital, University of Lyon, \\ Lyon; and the International Associated Laboratory IMPACT पा \\ (INSERM, France - Indian Council of Medical Research, India), \\ National Institute of Immunohematology, Mumbai, India
}

Th17 cells that secrete the cytokines IL-17A and IL-17F and express lineage-specific transcription factor RORC (ROR $\gamma \mathrm{t}$ in mice) represent a distinct lineage of $\mathrm{CD}^{+} \mathrm{T}$ cells. Transforming growth factor- $\beta$ and inflammatory cytokines, such as IL-6, IL-21, IL-1 $\beta$, and IL-23, play central roles in the generation of Th17 cells. Th17 cells are critical for the clearance of extracellular pathogens, including Candida and Klebsiella. However, under certain conditions, these cells and their effector molecules, such as IL-17, IL-21, IL-22, GM-CSF, and CCL20, are associated with the pathogenesis of several autoimmune and inflammatory diseases, such as rheumatoid arthritis, systemic lupus erythematosus, multiple sclerosis, psoriasis, inflammatory bowel disease, and allergy and asthma. This review discusses these disease states and the various therapeutic strategies under investigation to target Th17 cells, which include blocking the differentiation and amplification of Th17 cells, inhibiting or neutralizing the cytokines of Th17 cells, and suppressing the transcription factors specific for Th17 cells. (AmJ Pathol 2012, 181:8-18; bttp:/) dx.doi.org/10.1016/j.ajpath.2012.03.044)

$\mathrm{CD}^{+} \mathrm{T}$ cells are central in the process of immune response generation by coordinating with different immune cells. As effector cells, they are critical for the generation, sustenance, and regulation of immune responses against pathogens and self-antigens. CD4 ${ }^{+} \mathrm{T}$ cells are heterogeneous, and several subsets have been identified based on their distinct cytokine and transcription factor profiles. These subsets include Th1, Th2, and $\mathrm{CD} 4^{+} \mathrm{CD} 25^{+}$regulatory $\mathrm{T}$ cells (Tregs). Although other $\mathrm{T}$-cell subsets, such as transforming growth factor (TGF)- $\beta$-producing Th3 cells, IL-10-secreting T-regulatory type 1, IL-9-producing Th9 cells, and IL-22-producing Th22 cells, have been described, their lineage-specific transcription factors have not been identified. More recently, Th17 cells that secrete cytokines IL-17A and IL-17F and express surface IL-23 receptor (IL-23R) and lineagespecific transcription factor RORC (ROR $\gamma$ t in mice) have been identified as a distinct lineage of $C D 4^{+} \mathrm{T}$ cells. ${ }^{1-4}$ Although Th17 cells share several surface markers with other $\mathrm{CD} 4^{+} \mathrm{T}$ cell subsets, recent results demonstrate that $\mathrm{CCR}^{+}{ }^{+} \mathrm{CR} 4^{+}$or $\mathrm{CCR}^{+}{ }^{+} \mathrm{CR} 5^{-}$ memory $\mathrm{CD}^{+}{ }^{+} \mathrm{T}$ cells are bona fide Th17 cells, indicating that the Th17 population in the periphery is not homogeneous. ${ }^{5-7}$ In addition, human Th17 cells specifically express lectin receptor CD161. 6,8 Th17 cells play critical roles in the clearance of extracellular pathogens, including Candida and Klebsiella. However, under certain conditions, these cells can also be associated with the pathogenesis of various autoimmune and inflammatory diseases.

Supported by grants from the Institut National de la Santé et de la Recherche Médicale (INSERM), the Centre National de la Recherche Scientifique (CNRS), the Université Pierre et Marie Curie, the Université Paris Descartes, and the European Community's Seventh Framework Programme (FP7-2007-2013) under Grant Agreement No. HEALTH-F2-2010260338-ALLFUN.

Accepted for publication March 15, 2012.

Address reprint requests to Jagadeesh Bayry, D.V.M., Ph.D., INSERM Unité 872, Centre de Recherche des Cordeliers, 15 rue de l'Ecole de Médicine, Paris, F-75006, France. E-mail: jagadeesh.bayry@crc. jussieu.fr. 


\section{Biology of Th17 Cells and Regulation of Their Differentiation}

In the periphery, naïve CD4 ${ }^{+} \mathrm{T}$ cells on interaction with antigen-presenting cells can undergo differentiation into distinct lineages under the influence of specific cytokines. Extensive studies in recent years have contributed to an in-depth understanding of the generation and function of Th17 cells.

\section{Th17 Differentiation in Mice}

Several groups convincingly showed that TGF- $\beta$ and IL-6, two cytokines with opposing effects, synergize to induce orphan nuclear receptor ROR $\gamma$ t, which orchestrates the expression of IL-17A and IL-17F in naïve T cells (Figure 1). ${ }^{2-4} \mathrm{IL}-6$ is a proinflammatory and pleiotropic cytokine secreted in high amounts by the innate cells, $B$ cells and subsets of activated T cells. In addition, tumor cells, fibroblasts, endothelial cells, and keratinocytes can contribute to IL-6. Although TGF- $\beta$ is produced by multi-

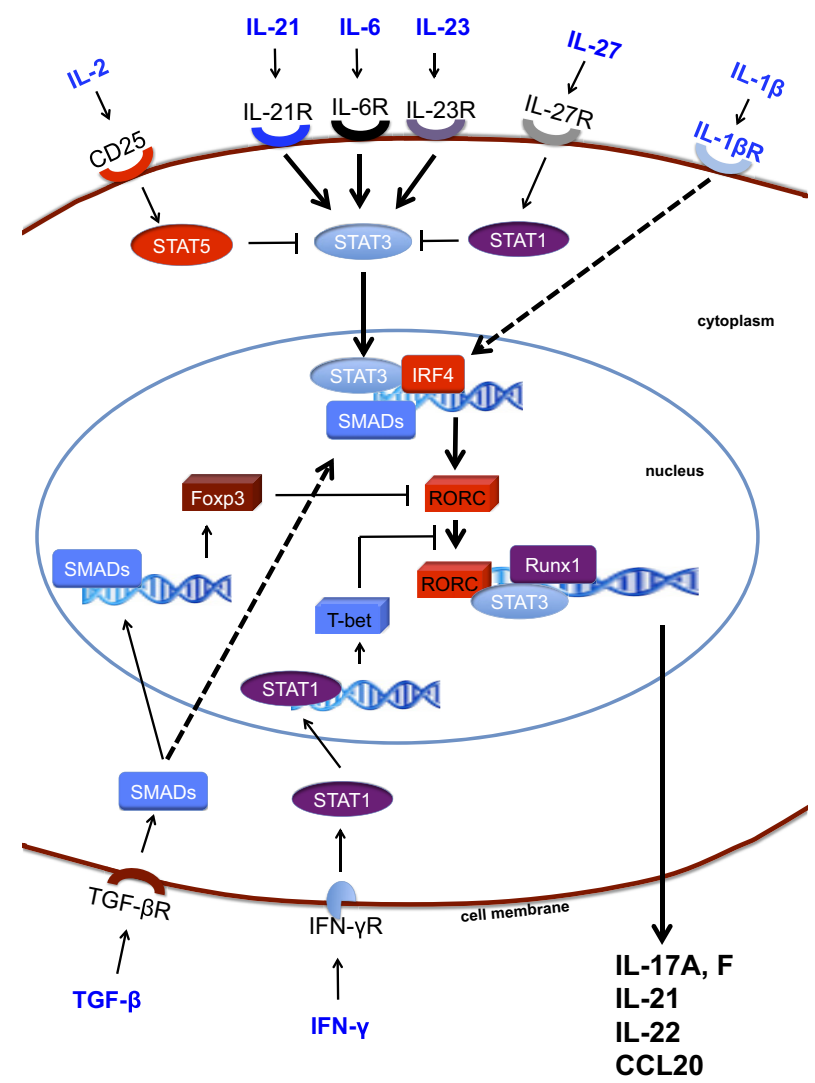

Figure 1. Mechanisms of Th17 cell induction. TGF- $\beta$ is essential for the generation of both induced regulatory T cells and Th17 cells via the induction of FoxP3 and RORC. However, in the absence of inflammation, FoxP3 represses RORC and promotes iTregs. Signaling via inflammatory cytokines, such as IL-6, IL-21, and IL-23, results in STAT3 phosphorylation, relieves RORC from the suppression of FoxP3, and initiates Th17 programming. STAT3 in combination with IFN regulatory factor 4 (IRF4) further induces RORC expression. The transcription factors STAT3, RORC, and Runx 1 bind to the promoter regions of the IL17,IL21,IL22, and CCL2O genes and induce IL-17, IL-21, IL-22, and CCL20. Th17 programming can be antagonized by cytokines, such as IFN- $\gamma$, IL-2, and IL-27. IL-2-mediated and IL-27-mediated activation of STAT5 and STAT1 inhibit STAT3, whereas T-bet induced by IFN- $\gamma$ can block RORC. ple lineages of leukocytes and stromal cells, an autocrine or paracrine source of TGF- $\beta$ is found to be important for Th17 differentiation in vivo. ${ }^{3,9,10}$ Thus, Treg-derived TGF- $\beta$ enables differentiation of Th17 cells when naïve T cells are co-cultured with activated dendritic cells (DCs). Th17 cells can also express high amounts of TGF- $\beta$, and this cytokine can act in an autocrine manner to maintain Th17 cells in vivo. ${ }^{10}$ Further, tumor necrosis factor (TNF)- $\alpha$ and IL-1 $\beta$ are found to enhance TGF- $\beta$-mediated and IL-6-mediated differentiation of Th17 cells. ${ }^{2}$

Because IL-6 knockout mice are found to be susceptible to experimental autoimmune encephalomyelitis (EAE) on depletion of Tregs, factors other than IL-6 are proposed to play roles in the induction of Th17 cells. TGF- $\beta$ is found to synergize with IL-21 to induce ROR $\gamma$ t and IL-17 in naïve T cells. ${ }^{11,12}$ Because Th17 cells are the major producers of IL-21, an autocrine amplification loop is established by IL-21 to enhance their differentiation. ${ }^{11-13}$ It is also believed that in the absence of inflammation, when IL-6 levels are low, IL-21 produced by Th17, NK, and NKT cells is important both to maintain and to amplify the pool of Th17 precursors. ${ }^{11,14}$ Thus, IL-21 has a major role in supporting Th17 cell differentiation and tissue inflammation.

$\mathrm{IL}-23$ is another inflammatory cytokine that contributes to Th17 generation. The combination of TGF- $\beta$ and IL-6/ IL-21 induces surface IL-23R on differentiating Th17 cells. Differentiating Th17 cells become responsive to activated myeloid cell-produced IL-23. ${ }^{4,12,13}$ IL-23 (p19) deficiency is associated with a reduced number of Th17 cells in vivo. IL-23 is also required for the maintenance of Th17 cells in vitro, for the induction of tissue inflammation by in vitro-generated Th17 cells, and for Th17-mediated chronic inflammation in vivo. ${ }^{9,15}$ IL-23 synergizes with IL-6 to enhance differentiation, survival, and stabilization of Th17 cells. ${ }^{13,15}$ IL-23 can amplify Th17 cells by inducing proinflammatory cytokines, such as IL-1 $\beta$, TNF- $\alpha$, and IL-6, in innate immune cells. ${ }^{14}$ Thus, complete Th17 cell differentiation was proposed to comprise three different stages. The first stage is differentiation of Th17 cells triggered by the combined effect of TGF- $\beta$ and IL-6/IL-21. The second stage is amplification of Th17 cells driven by IL-21 produced by Th17 cell themselves, probably with TGF- $\beta$. The third stage is stabilization of Th17 cells by IL-23. ${ }^{14}$

Despite these convincing findings regarding the requirement of cytokines (TGF- $\beta$, IL-6, IL-21, IL-23) for Th17 differentiation in mice, the absolute requirement of TGF- $\beta$ has been questioned more recently. Th17 cells are present in the gut of TGF- $\beta$ signaling-deficient mice. ${ }^{16,17}$ In T-bet-deficient and STAT6-deficient murine T cells, production of IL-17 could be induced by IL-6 alone in the absence of TGF- $\beta .{ }^{18} \mathrm{IL}-6$ and $\mathrm{IL}-23$ in combination with $\mathrm{IL}-1 \beta$ were able to induce $\mathrm{IL}-17$ production in the absence of TGF- $\beta$ signaling, ${ }^{17}$ suggesting an alternative mode of Th17 cell differentiation. Th17 cells generated in the absence of TGF- $\beta$ exhibit a phenotype of T-bet ${ }^{+} \mathrm{ROR} \gamma \mathrm{t}^{+}$and are pathogenic in vivo. However, this phenotype requires further validation because Th17 cells display profound instability as discussed later. 


\section{Th17 Differentiation in Humans}

Once the factors driving the differentiation of Th17 cells in mice were revealed convincingly, different cytokine combinations were examined to generate RORC-expressing human Th17 cells. Initially, it was argued that human Th17 differentiation is not dependent on TGF- $\beta$ signaling, which is in contrast to murine Th17 cells. It was proposed that the combination of IL-1 $\beta$ and IL-6/IL-23 or IL-23 alone could differentiate human Th17 cells from naïve $T$ cells. ${ }^{19,20}$ These results are biased because the differentiation of Th17 cells in these reports was performed using CD45RA $^{+}$Th cells purified from peripheral blood. Additionally, the endogenous source of TGF- $\beta$ (eg, serum and platelets) was not carefully controlled in those reports. Subsequent studies done with serum-free medium and rigorously sorted naïve $T$ cells resolved these issues, establishing that, similar to murine Th17 cells, TGF- $\beta$ is indispensable for the differentiation of human Th17 cells from naïve $T$ cells. ${ }^{21-23}$ It is also believed that human Th17 cells can originate from a small subset of $\mathrm{CD} 161^{+} \mathrm{RORC}^{+}$precursors present in umbilical cord blood and thymus in response to a combination of IL-23 and IL-1 $\beta$, even in the complete absence of TGF- $\beta .^{24}$ In our opinion as discussed subsequently, this setting mimics an expansion of a pre-existing Th17 population rather than the differentiation of de novo Th17 cells.

TGF- $\beta$ is essential for the induction of RORC in naïve T cells, although the expression and functions of RORC are inhibited at high concentrations of TGF- $\beta .^{22}$ However, inflammatory cytokines, such as IL-21, IL-1 $\beta$, IL-6, and IL-23, relieve the inhibition of RORC in $\mathrm{CD} 4^{+} \mathrm{T}$ cells and trigger the expression of IL-17 (Figure 1). ${ }^{21-23}$ Essentially, naïve $T$ cells do not express IL-1R and IL-23R. However, these receptors are induced after exposure to TGF- $\beta$ and $\mathrm{IL}-6 / \mathrm{IL}-21$, making the cells receptive to IL-1 $\beta$ and IL$23 .^{21,25}$ It has been shown that the combination of TGF- $\beta$ and IL-21 is sufficient to induce the differentiation of human Th17 cells from naïve T cells, and IL- $1 \beta$ and IL-6 are important for enhancing the expansion of differentiated and memory Th17 cells. ${ }^{21}$ TGF- $\beta$ also favors human Th17 differentiation indirectly because of its suppressive activity on T-bet expression and the generation of Th1 cells. ${ }^{26}$ Thus, cytokine requirements for driving the differentiation of Th17 cells are similar in both humans and mice.

\section{Mechanistic Pathways in Th17 Cell Differentiation and Expression of Effector Molecules}

Differentiation of Th17 cells requires the cooperative interaction of downstream molecules of TGF- $\beta$ and IL-6 receptor-mediated signaling pathways (Figure 1). Basically, naïve $T$ cells are receptive to IL-6 because these cells express functional IL-6 receptor. IL-6 receptor consists of the inducible subunit IL-6R $\alpha$ and the constitutively expressed signaling subunit gp130. Although T-cell receptor stimulation and IL-6 signaling down-regulate IL$6 \mathrm{R} \alpha$ expression on naïve T cells, TGF- $\beta$ can maintain the receptiveness of $T$ cells to $\mathrm{IL}-6$ by inducing the expres- sion of $\mathrm{IL}-6 \alpha$. Binding of $\mathrm{IL}-6$ to its receptor activates STAT3 but is transient owing to the induction of suppressor of cytokine signaling 3 (SOCS3).

STAT3 activation is necessary but not sufficient for ROR $\gamma$ t expression. TGF- $\beta$ signaling through its receptor (ie, the TGF $\beta$ RI-TGF $\beta$ RII complex) activates the Smad2 pathway, leading to the expression of both Foxp3 and ROR $\gamma$ t. $^{27}$ TGF- $\beta$ signaling through Smad2/3 inhibits IL-6induced and IL-21-induced SOCS3 expression, enhancing and prolonging STAT3 activation in naïve T cells. ${ }^{16,27}$ Sustained activation of STAT3 in the presence of IL-6 and TGF- $\beta$ relieves Foxp3-mediated suppression of $\mathrm{ROR} \gamma \mathrm{t}$, enhances ROR $y$ t expression, and facilitates the Th17 transcriptional program. Smad-independent induction of Th17 cells by TGF- $\beta$ has also been described. TGF- $\beta$ can induce $\mathrm{ROR} \gamma \mathrm{t}$ expression and Th17 cell differentiation by signaling through the JNK-C-Jun pathway and by suppressing Eomesodermin, a negative regulator of Th17 cells. ${ }^{28}$

TGF- $\beta$-induced and IL-6-induced STAT3 activation also induces the expression of another related nuclear receptor, $\mathrm{ROR} \alpha$, which synergizes with $\mathrm{ROR} \gamma \mathrm{t}$ in Th17 cell differentiation. In cooperation with STAT3, both $\mathrm{ROR} \gamma \mathrm{t}$ and $\mathrm{ROR} \alpha$ bind to the $\mathrm{IL}-17$ promoter region, leading to competent induction of IL-17A, IL-17F, and IL-21. ${ }^{29,30}$ In view of the similar and redundant role to that of ROR $\gamma$ t, ROR $\alpha$ is believed to be a minor player in Th17 cell differentiation.

IL-23 signaling through IL-23R (induced by TGF- $\beta$ and IL-6/IL-21) further enhances the activation of STAT3, which is coordinated with ROR $\gamma$ t to stabilize Th17 cells and their function. ${ }^{30} \mathrm{IL}-6$ signaling enhances the expression of IL-1R on differentiating Th17 cells. IL-1 $\beta$ acts in synergy with IL-6 and IL-23 for the polarization of Th17 cells by regulating the expression of interferon regulatory factor 4 (IRF4), which favors the functional expression of ROR $y \mathrm{t}^{31,32}$ Therefore, based on the activation state of $\mathrm{T}$ cells that are differentially receptive to various cytokine signals, the cytokines required for Th17 lineage commitment vary. This variability may explain the observed discrepancies in the Th17 differentiation models of initial studies.

In addition to the key regulators, other transcription factors, such as Baft (AP-1 transcription factor family), $\left.\right|_{\kappa} \mathrm{B} \zeta$ (nuclear $\mid \kappa \mathrm{B}$ family), and Runx1 (member of core-binding factor- $\alpha$ ), are found to be essential for enhancing the Th17 differentiation and expression of effector molecules. ${ }^{33-35}$ Thus, Th17 differentiation appears to be governed by multiple cytokine signals and transcription factors.

\section{Reciprocal Regulation of Th17 and iTregs}

In addition to natural Tregs (nTregs) that are of thymic origin, Tregs can be induced (iTregs) in the periphery under specific conditions. Developmental pathways of Th17 cells and iTregs are closely related, are reciprocally regulated, and can influence the outcome of immune responses, particularly in autoimmune and inflammatory diseases. ${ }^{36}$ TGF- $\beta$ is the critical factor in common for Th17 cells and iTregs because it is essential for inducing both ROR $y$ t and Foxp3. However, in the absence of inflammation, the prominent TGF- $\beta$ alone induces Foxp3, leading to the generation of iTregs that maintain immune 
tolerance along with nTregs. On a molecular level, TGF$\beta$-induced FoxP3 physically associates with ROR $\gamma$ t and $\mathrm{ROR} \alpha$ via Runx1. Through this interaction, FoxP3 antagonizes the expression and function of both RORyt and $\mathrm{ROR} \alpha$, leading to the inhibition of the Th17 transcriptional program. ${ }^{35,36}$ Accordingly, Foxp $3^{+} \mathrm{ROR} \gamma \mathrm{t}^{+}$cells present in the small intestine produce less IL-17 compared with Foxp3 ${ }^{-} \mathrm{ROR} \gamma \mathrm{t}^{+}$cells. $^{36}$ Following an inflammatory trigger, the proinflammatory cytokines IL-6, IL-21, and IL-23 induce STAT3, blocking TGF- $\beta$-driven Foxp3 expression, inhibiting Tregs, and exploiting TGF- $\beta$ signaling to enhance ROR $y$ t-expressing Th17 cells. Therefore, IL-6 and IL-21 have important roles in the reciprocal regulation of iTregs and Th17 cells by controlling the Foxp3/RORyt balance (Figure 1). 3,11,13,36,37

IL-2, a growth factor for Tregs, also fortifies the cellintrinsic reciprocal developmental relationship between Foxp3+ Tregs and Th17 cells. IL-2 induces phosphorylation of STAT5, and STAT5 can oppose Th17 differentiation by binding to the il17a gene. ${ }^{38} \mathrm{IL}-2$ can also inhibit Th17 cells via Ets-1, a member of the ETS family of transcription factors, which negatively regulates Th17 differentiation. ${ }^{39}$ Further, IL-2 decreases the expression of IL-6R, a key molecule implicated in Th17 polarization. ${ }^{40}$

Retinoic acid, a vitamin A metabolite, can reciprocally regulate Tregs and Th17 via the TGF- $\beta 1$-dependent generation of Foxp3+ Tregs, even in the presence of IL-6. ${ }^{41,42}$ Retinoic acid-induced Foxp3 ${ }^{+}$Tregs have a unique feature of high expression of gut homing receptors. ${ }^{41}$ Mechanistically, retinoic acid enhances TGF- $\beta 1$-driven Smad3 phosphorylation in naïve $T$ cells, possibly via nuclear retinoic acid receptor- $\alpha$, while inhibiting the up-regulation of IL-6R $\alpha$ subunit, IRF4, and IL-23R. ${ }^{41}$

The ligand-activated transcription factor, aryl hydrocarbon receptor (AHR), can also exert reciprocal regulation of Treg and Th17 cell differentiation in mice, a process dependent on the ligands. ${ }^{43}$ AHR activation by 2,3,7,8-tetrachlorodibenzo-p-dioxin (TCDD) induces functional Tregs, whereas 6-formylindolo[3,2-b]carbazole (FICZ) interferes with Treg development and boosts Th17 cell differentiation in EAE. ${ }^{43-45}$ In contrast, in human T cells, AHR activation by TCDD induces Foxp3 ${ }^{+}$Tregs, whereas FICZ profoundly enhances IL-22 production while decreasing IL-23R and IL-17A in Th17 cells. ${ }^{46}$ AHR can be considered an intriguing link between environmental toxins and immune equilibrium.

Contrary to the cell-intrinsic reciprocal regulation of Tregs and Th17 cells, more recent studies have shown that Tregs complement Th17 differentiation. 2,10,47,48 Tregs may serve as the source of TGF- $\beta$ required for the induction of ROR $y$ in Th17 cells. ${ }^{2}$ Additionally, Tregs can promote early Th17 differentiation through the consumption of IL-2 that otherwise suppresses Th17 cell programming by the paracrine activation of STAT5 ${ }^{47,48}$

\section{Relationship Between Th17 and Th1/Th2 Cells}

Th1 and Th2 cytokines, IFN- $\gamma$ and IL-4, are known to inhibit the development of Th17 cells by paracrine and cell-intrinsic actions. ${ }^{1}$ These effects are mediated by the mutual antagonism between lineage-specific transcrip- tion factors. ${ }^{49}$ IFN- $\gamma$ enhances T-bet expression, which interacts with the Runx1-ROR $y$ t complex to inhibit Th17 differentiation. ${ }^{49}$ Further, IL-27 negatively regulates Th17 cells and promotes Th1 cell responses in a STAT1-dependent manner by inducing IL-10 in Th cells. ${ }^{50-52}$

IL-4-induced GATA3 might constrain Th17 differentiation in vitro through IL-4-independent mechanisms, involving the down-regulation of STAT3, NFATC2, and ROR $y$ t. $^{53}$ In view of the inhibitory effects of IFN- $\gamma$ and IL-4 on Th17 cells, it is proposed that TGF- $\beta$-mediated repression of Th1/Th2 cells is critical for Th17 differentiation. In contrast, Th17-related cytokines such as IL-23 and IL-17 are found to suppress murine Th1 cell differentiation in vitro in the presence of exogenous IL-12.

\section{Stability of Th17 Cells}

Compared with Th1, Th2, and nTregs, Th17 cells display instability. In mice and humans, Th17 cells co-expressing IL-17/IFN- $\gamma$, ROR $\gamma t / T-$ bet, or FoxP3/L-17/ROR $\gamma$ t have been observed during inflammatory responses. ${ }^{5,6,17,20,36,54} \mathrm{Hu}-$ man circulating memory Th cells co-expressing IL-17A/IL-4 have also been identified. ${ }^{55}$

The acquisition of a mixed phenotype by Th17 cells appears to be determined by the inflammatory environment (and hence the cytokine milieu), as chronic inflammatory conditions such as EAE can cause a switch to alternative inflammatory cytokines in Th17 cells. ${ }^{56}$ Surprisingly in this model, IL-23, which is considered the stabilizing factor for Th17 cell commitment, was found to mediate the transformation of Th17 cells to produce IFN- $\gamma$ and other inflammatory cytokines under chronic inflammatory conditions. ${ }^{56}$ IFN- $\gamma$ can up-regulate IL-12R $\beta 2$ on Th17 cells and enhance their sensitivity to IL-12, resulting in a Th17/Th1 phenotype that stably co-expresses ROR $y \mathrm{t}$ and T-bet. ${ }^{57}$ Under inflammatory conditions in the gastrointestinal tract, Th17 cells can also acquire a regulatory phenotype with immunosuppressive functions. ${ }^{58}$ On a molecular level, Th17 plasticity has been related to the bivalent epigenetic modification of histone proteins by methylation in the signature cytokine and key transcription factor genes. ${ }^{59}$

\section{Functions of Effector Molecules of Th17 Cells}

Th17 cells produce several effector molecules, such as IL-17A, IL-17F, IL-21, and IL-22 (Figure 2). In addition, Th17 cells produce CCL20, GM-CSF, IL-8, IL-26, and IL-10, although many of these cytokines are not Th17specific.

IL-17A is the prototype member of the IL-17 family, consisting of six cytokines: IL-17A, IL-17B, IL-17C, IL17D, IL-17E (IL-25), and IL-17F. IL-17A and IL-17F have similar functions and are genetically linked. They are presumably expressed under the control of the same locus and are often co-expressed at the single-cell level. ${ }^{14}$ Both IL-17A and IL-17F use the IL-17 receptor A (IL-17RA)-IL-17RC heterodimer for their signaling, although IL-17A binds IL-17RA with much higher affinity. Binding of IL-17 to its receptor recruits adapter protein 


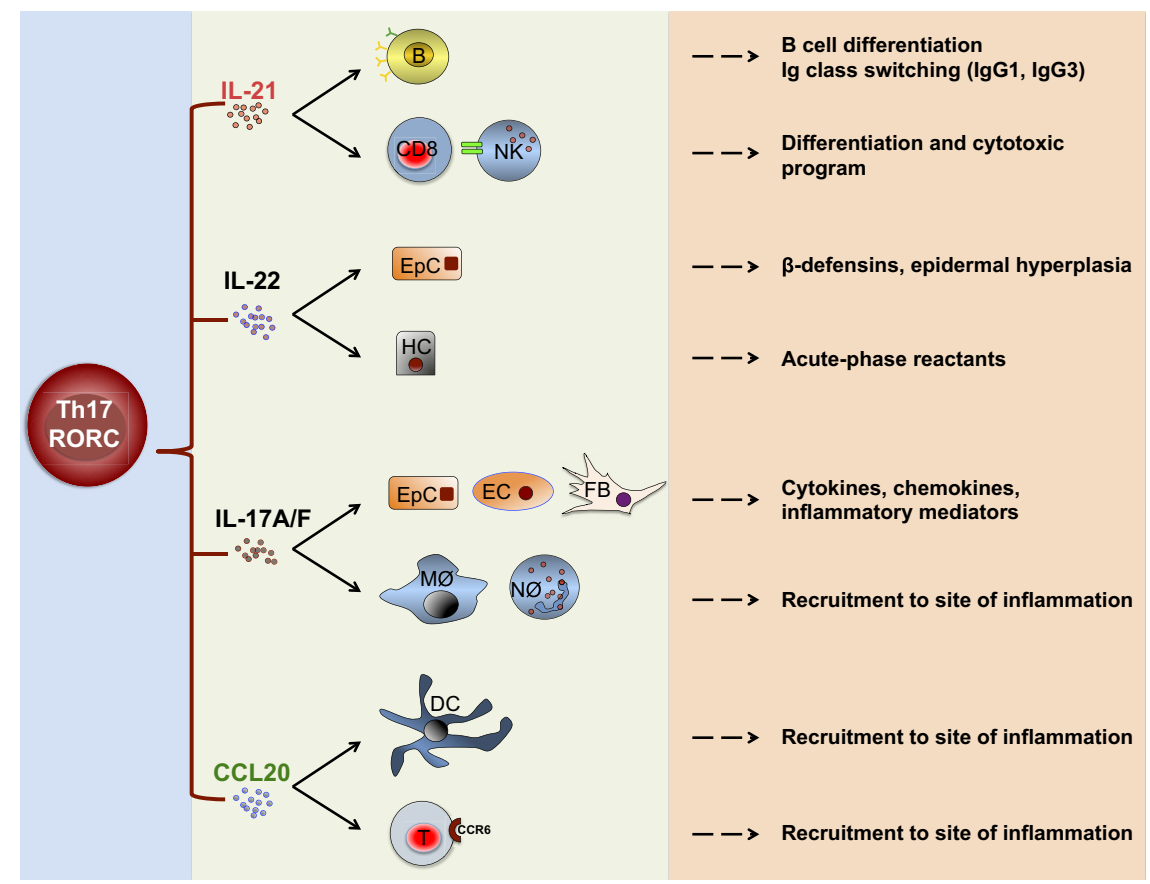

Figure 2. Functions of Th17 cytokines and chemokines. Th17 cells secrete several effector molecules, including IL-21, IL-22, IL-17A/F, and CCL20. These soluble factors act on both immune and nonimmune cells and mediate several functions, such as differentiation of cells; release of antimicrobial molecules, cytokines, and chemokines; and recruitment of cells to sites of inflammation. B, B cell; CD8, cytotoxic T cell; DC, dendritic cell; EC, endothelial cell; EpC, epithelial cell; FB, fibroblast; HC, hepatic cell; M $\varnothing$, macrophage; NK, natural killer cell; NØ, neutrophil; T, T cell.
ACT1, which further stimulates TNF receptor-associated factor 6 to activate the NF- $\kappa$ B and MAPK pathways. ${ }^{14}$ Both IL-17A and IL-17F are key cytokines for the recruitment, activation, and migration of neutrophils and can target nonimmune cells, such as fibroblasts, endothelial cells, airway smooth muscle cells, and epithelial cells, to induce pro-inflammatory mediators IL-6, TNF- $\alpha, \mathrm{IL}-1 \beta$, GM-CSF, G-CSF, PGE2, nitric oxide, matrix metalloproteinases, and chemokines (CXCL1, CXCL8, CCL2, CCL7, and CCL20). ${ }^{1,14} \mathrm{IL}-17$ also regulates germinal-center formation and autoantibody production.

IL-22 belongs to the IL-10 family of cytokines and is produced by terminally differentiated Th17 cells through IL-23-mediated STAT3 activation. ${ }^{14}$ AHR, a receptor for digoxin, plays an important role in the expression of IL22. ${ }^{44}$ The IL-22 receptor consists of a unique IL-22R 1 chain and IL-10R2 and is highly expressed in epithelial cells and parenchymal tissues but not on immune cells. Through this receptor complex, IL-22 activates the STAT3 and MAPK pathways. IL-22 induces antimicrobial agents and $\beta$-defensins in keratinocytes and promotes epidermal hyperplasia. Therefore, IL-22 is essential for the immune barrier function of epithelial cells. ${ }^{14}$

IL-21 is a member of the IL-2 family of cytokines and mediates its functions via the $\mathrm{IL}-21$ receptor, which is expressed mainly on B cells but also on T cells and other myeloid cells. ${ }^{14} \mathrm{IL}-21$ receptor is a heterodimer of IL-21R and the common cytokine-receptor $\gamma$ chain $\left(\gamma_{c}\right)$. Binding of IL-21 to its receptor complex activates JAK1 via IL-21R and JAK3 via $\gamma_{c}$, leading to STAT3 activation. In addition to the differentiation of Th17 cells, IL-21 stimulates i) proliferation and differentiation of $\mathrm{CD}^{+} \mathrm{T}$ cells in combination with IL-7 or IL-15; ii) B cell differentiation and antibody class switching (IgG1, IgG3) by inducing Blimp-1 and Bcl-6; iii) differentiation and cytotoxic pro- gram of NK and NKT cells; and iv) IL-8 production from DCs and macrophages.

CCL20 is a ligand for CCR6 expressed by DCs, B cells, and subsets of $T$ cells and has antimicrobial and chemoattractive activities. Th17 cells also express CCR6; through CCL20 secretion, Th17 cells regulate their own recruitment to inflamed tissues. Further, CCL20 can be induced by IL-17 in tissues, indicating that CCL20 might have an important role in sustaining Th17-mediated inflammation.

\section{Th17 Cells in Autoimmune and Inflammatory Conditions}

Th17 cells and their cytokines are associated with several autoimmune and inflammatory diseases, such as rheumatoid arthritis (RA), systemic lupus erythematosus (SLE), multiple sclerosis (MS), psoriasis, inflammatory bowel disease (IBD), and allergy and asthma. ${ }^{60,61}$

\section{Rheumatoid Arthritis}

The prevalence of $\mathrm{IL}-17^{+}$and $\mathrm{IL}-22^{+} \mathrm{CD} 4^{+}$cells is increased in the circulation of patients with RA and ankylosing spondylitis; these cells produce higher quantities of IL-17 after stimulation. ${ }^{62} \mathrm{IL}-17$ is also present at the sites of inflammatory arthritis and amplifies the inflammation induced by other cytokines and, in particular, TNF- $\alpha$. In a collagen-induced arthritis (CIA) model, the disease is mainly mediated by IL-17 because IL-17 deficiency, or treatment with IL-17RA antagonist or with IL-17-neutralizing antibody before disease onset, attenuates arthritis with decreased joint damage and reduced serum IL-6. ${ }^{63}$

$\mathrm{IL}-21$ is up-regulated in the synovium, synovial fluid, and serum of patients with early-stage RA and CIA mice 
and is correlated with disease activity ${ }^{64} \mathrm{IL}-21$ regulates Th17 cells and promotes osteoclastogenesis in RA. ${ }^{64}$ Inhibition of the IL-21/IL-21 receptor pathway ameliorates arthritis in animal models. ${ }^{65}$

IL-22 levels in the sera of patients with RA are associated with radiographic progression of the disease. ${ }^{66,67}$ These findings are substantiated in experimental arthritis in mice, wherein the increased expression of IL-22 by synovial Th17 cells was observed during late stages of the disease. ${ }^{66,67} \mathrm{IL}-22$ can also promote osteoclastogenesis and regulate antibody production in arthritis.

Different effector molecules of Th17 cells synergize to enhance disease activity in RA. However, more recent studies indicate the transient phenotypic nature of $\mathrm{CD} 4{ }^{+} \mathrm{CD} 161^{+}$Th17 cells in the synovial fluid of patients with RA and juvenile idiopathic arthritis. ${ }^{68,69}$

\section{Systemic Lupus Erythematosus}

Patients with SLE exhibit increased levels of IL-23, IL-21, and IL-17 as a result of expansion of Th17 cells. These changes are associated with the depleted Treg population and increased Th17/Th1 ratio. ${ }^{70}$ In patients with SLE and in experimental models, IL-17 in coordination with IL-21 and BAFF promotes germinal center formation and influences B cells to produce pathogenic autoantibodies. ${ }^{71,72}$ The genetic association of SLE with polymorphisms of Th17-encoding molecules (eg, IL-21 ${ }^{73}$ or their receptors (eg, IL-21R) has been reported. ${ }^{74}$ In addition, genetic variants of transcription factors (eg, ETS1) that negatively regulate Th17 differentiation can predispose to SLE. ${ }^{75}$ Blocking of the IL-21 pathway ameliorates the autoimmune symptoms in a mouse model of SLE. ${ }^{76}$

\section{Multiple Sclerosis}

In patients with MS, IL-17 expression is augmented in mononuclear cells of the blood and cerebrospinal fluid and at the site of lesions. ${ }^{77,78} \mathrm{LL}-17$ expression is correlated with disease activity. IL-17 and IL-22 promote blood-brain barrier disruption and central nervous system inflammation by inducing chemokines in endothelial cells and by downregulating tight junction proteins. IL-17 also stimulates astrocytes to produce ELR ${ }^{+}$CXC chemokines that eventually attract neutrophils to the blood-brain barrier and activate them to release vasoactive substances. ${ }^{79}$

IL-23 (but not IL-12) that expands IL-17-producing Th cells is critical for the induction of EAE. It has been shown that myelin antigen-specific Th17 cells directly interact with neuronal cells in demyelinating lesions. ${ }^{80,81}$ Either deficiency or neutralization of IL-17 delays the onset of EAE and reduces the severity of disease. ${ }^{80} \mathrm{~A}$ more recent study further revealed that under chronic inflammatory conditions, such as EAE, Th17 cells display plasticity. Thus, in inflamed tissues, Th17 cells can switch from IL-17 to other inflammatory cytokines, in particular, to IFN- $\gamma^{56}$

Two independent studies have identified the critical nonredundant role of Th17-produced GM-CSF in the pathogenesis of EAE. ROR $\gamma$ t drives the production of GM-CSF in Th17 cells under the influence of the IL-1 and IL-23 pathways. GM-CSF acts on antigen-present- ing cells (and, in particular, $\mathrm{CD} 103^{+}$dermal DCs) to stimulate the secretion of IL-23 and the activation of encephalitogenic T cells, creating a positive feedback loop during inflammation. ${ }^{82-84}$ In consensus, absence of GMCSF confers resistance to EAE in mice, even in the presence of IL-17 and/or IFN- $\gamma^{82}$

\section{Psoriasis}

Psoriatic skin lesions are infiltrated by discrete populations of highly differentiated Th1 and Th17 lymphocytes. ${ }^{20,85} \mathrm{IL}-23$, overproduced by dermal DCs and keratinocytes, stimulates Th17 cells within the dermis to elevate the amounts of IL-17, TNF- $\alpha, I L-22$, and CCL20. These soluble mediators of Th17 cells might further enhance inflammation by their distinct actions. For example, CCL20 can attract CCR6 ${ }^{+}$cells to lesions, and IL-17 can induce IL-6 and IL-8 in human skin keratinocytes.

An experimental model of psoriasis-like skin inflammation indicates that IL-22 plays a central role in Th17 cellmediated skin pathology. ${ }^{86} \mathrm{IL}-22$ mRNA expression mirrored IL-17 in psoriatic skin. IL-22 mRNA expression returned to nonlesional levels on treatment with cyclosporine, a conventional therapy for psoriasis. ${ }^{85} \mathrm{IL}-22$ also stimulates proliferation, abnormal differentiation, and migration of various epithelial cells in vitro.

\section{Inflammatory Bowel Disease}

Crohn's disease (CD) and ulcerative colitis (UC) are the major, immunologically distinct forms of IBD in humans. CD-related inflammation is characterized by a marked mucosal infiltration of T cells that secrete Th1 and Th17 cytokines. In UC, the local immune response is less polarized but may show enhanced production of IL-5, IL-13, and Th17 cytokines. ${ }^{87}$

Th17 cells generally are considered to be more potent than Th1 cells in transferring IBD. ${ }^{87}$ Elevated levels of IL-17A, IL-17F, and IL-21 are observed in the sera of patients with active IBD. ${ }^{87}$ Colitic mice show an increased number of Th17 cells in the inflamed areas of the lamina propria of both the ileum and the colon. IL-21 can mediate Th17 differentiation and enhance inflammatory responses by recruiting T cells to the inflamed gut and by eliciting the secretion of matrix-degrading enzymes by gut fibroblasts. In addition, genetic studies have identified alleles of il-23r (among others) and their association with either predisposition or protection from IBD. ${ }^{87}$

In contrast to other Th17 cytokines, IL-22 was found to be protective in IBD through maintaining the integrity of the epithelial barrier and protecting mucin-secreting goblet cells. ${ }^{88}$ Thus, Th17 cytokines have differential effects on the course and pathogenesis of IBD, and the net effect of these cytokines possibly depends on their relative abundance.

\section{Allergy and Asthma}

IL-17 mediates recruitment of neutrophils and can activate airway smooth muscle cells and epithelial cells to induce proinflammatory mediators. IL-23 and Th17 cells 
can also up-regulate Th2 cell-mediated eosinophilic airway inflammation. ${ }^{1,14}$ Therefore, in addition to Th2 cells that are traditionally considered pathogenic in allergy and asthma, Th17 cells can play a key role in airway inflammation.

In asthmatic patients, IL-17A/F expression is increased in the lungs, sputum, bronchoalveolar lavage fluids, or sera and is correlated with the severity of airway hypersensitivity. ${ }^{61}$ The number of Th17 cells and the expression of RORC were also enhanced in the peripheral blood of asthmatic patients, and these cells produced high amounts of Th17 cytokines on ex vivo activation.

A more recent report showed that Th17 cells show plasticity in asthma conditions, wherein patients display CCR6 ${ }^{+} \mathrm{CD} 161^{+} \mathrm{CD} 4{ }^{+} \mathrm{T}$ cells that co-express IL-17A/IL-4 in the circulation. ${ }^{55}$ It was found that memory Th17 cells express IL-4R and are responsive to IL-4 that induces STAT6 phosphorylation. ${ }^{55}$ This report suggests an interplay of Th2 and Th17 cells, wherein the IL-4-rich environment created by Th2 cells (along with other cells such as basophils) can provoke plasticity in Th17 cells and generate a Th17/Th2 phenotype that might aggravate the disease further.

IL-17A can play a role in the pathogenesis of asthma and allergy via the modulation of the expression of glucocorticoid receptors (GRs). Owing to alternative splicing of the GR pre-mRNA, GRs are expressed as two highly homologous isoforms: GR $\alpha$ and GR $\beta$. GR $\alpha$ is a ligandactivated transcription factor that mediates the expression of glucocorticoid-responsive genes. GR $\beta$ is transcriptionally inactive and does not bind glucocorticoids. However, GCR $\beta$ can act as an endogenous inhibitor of glucocorticoid function. It was found that IL-17A enhances the expression of GR $\beta$ and may cause steroid unresponsiveness or resistance in patients. ${ }^{89}$ Further, IL17A can mediate allergic reactions by promoting IgE class-switch recombination in B cells by stimulating $\varepsilon$ germline transcripts. ${ }^{61,90}$

\section{Strategies to Target Th17 Cells and Their Cytokines}

Th17 cells exhibit diverse therapeutic targets. The possible therapeutic strategies are i) blocking the differentiation and amplification of Th17 cells, ii) inhibiting or neutralizing the cytokines of Th17 cells, and iii) inhibiting the transcription factors specific for Th17 cells.

\section{Blocking the Differentiation and Amplification of Th17 Cells}

Innate immune cells and their inflammatory cytokines, such as IL-21, IL-23, IL-6, and IL-1 $\beta$, play critical roles in driving the differentiation and amplification of Th17 cells. Therefore, suppression of antigen-presenting cells, such as DCs and macrophages; inhibition of their inflammatory cytokines by neutralizing monoclonal antibodies; and blocking the receptors for inflammatory cytokines are expected to inhibit T-cell responses, including responses of Th17. ${ }^{91-93}$ Such strategies can also reciprocally regu- late Treg and Th17 populations. ${ }^{93,94}$ Blockade of the IL-21/IL-21 receptor pathway by IL-21R.Fc ameliorates the clinical and histological signs of $\mathrm{CIA} .{ }^{65}$ Although targeting IL-21R is specific for Th17 cells, other targets are not specific for Th17 cells because innate inflammatory cytokines have diverse and redundant functions.

Additional molecules explored for the inhibition of Th17 differentiation in vitro and in vivo in EAE models include AM-80, a synthetic retinoid that binds to the retinoic acidbinding site of retinoic acid receptors, and halofuginone, a derivative of plant alkaloid febrifuge that activates the amino acid starvation response. ${ }^{95,96}$

Ustekinumab, a human monoclonal antibody that targets the IL-12/IL-23 pathway by binding to the common p40 subunit, has shown promise for the treatment of psoriasis and CD. ${ }^{97,98}$ The success of ustekinumab in these diseases can be explained by the fact that both Th1 and Th17 cells are implicated in the pathogenesis of psoriasis and CD and that ustekinumab can inhibit both T-cell populations by inhibiting IL-12 and IL-23.

\section{Inhibiting or Neutralizing the Cytokines of Th17 Cells}

Specific targets include $\mathrm{IL}-17 \mathrm{~A} / \mathrm{F}$ and $\mathrm{IL}-21$, and less specific targets are IL-22, GM-CSF, and CCL20. 1,25Dihydroxyvitamin D3 ameliorates Th17 autoimmunity via the transcriptional modulation of IL-17A, while reciprocally inducing Foxp3. ${ }^{99} \mathrm{~N}$-acetylglucosamine inhibits both Th1/Th17 responses and myelin-oligodendrocyte glycoprotein-induced EAE by inhibiting the secretion of IFN- $\gamma$, TNF- $\alpha$, IL-17, and IL-22. ${ }^{100}$

More recently, the efficacy and safety of neutralizing humanized anti-IL-17A monoclonal antibodies AIN457 and LY2439821 were investigated. AIN457 induced clinically relevant responses of variable magnitude in patients with RA, psoriasis, and uveitis. ${ }^{101}$ Similarly, monoclonal antibody LY2439821 used in combination with oral disease-modifying antirheumatic drugs improved clinical signs and symptoms of RA, with no strong adverse effects. ${ }^{102}$ Further randomized clinical trials are required to confirm the benefits of anti-IL-17 monoclonal antibodies in RA and other diseases.

\section{Inhibiting Transcription Factors Specific for Th17 Cells}

The targets include ROR $y$ t/RORC and STAT3, which govern Th17 polarization and function. The nuclear receptor peroxisome proliferator-activated receptor gamma agonist, pioglitazone, inhibits human and murine Th17 differentiation by reducing the TGF- $\beta /$ IL-6-induced expression of ROR $y$ t/RORC. ${ }^{103}$ This inhibition of ROR $y$ t is associated with suppression of the development of central nervous system autoimmunity. ${ }^{103}$ Simvastatin, a cholesterol-lowering agent with immunomodulatory features, inhibits IL-17 by targeting multiple IL-17-regulatory cytokines and by suppressing the expression of RORC in human Th cells. ${ }^{104}$ More recently, the cardiac glycoside digoxin has been shown specifically to suppress murine and human 
Th17 cell differentiation by antagonizing ROR $\gamma$ t/RORC activity; it is also effective in delaying the onset and reducing the severity of EAE. ${ }^{105}$

Zinc, an essential trace element required for the maintenance of structure and activity of enzymes and transcription factors, suppresses Th17 cells by inhibiting STAT3 activation and is protective in both EAE and CIA. ${ }^{106}$ The platelet-activating factor receptor antagonist PCA-4248 suppresses psoriasis-like skin disease in experimental models by inhibiting the cytokines of Th1/Th17 cells and the Th17-specific transcription factor STAT3. ${ }^{107}$ More recently, leukemia inhibitory factor produced by neural progenitor cells was shown to ameliorate EAE via interference with the IL-6-induced STAT3 phosphorylation required for Th17 cell differentiation, while activating a signaling cascade that involves ERK and SOCS3. ${ }^{108}$

In addition, certain therapeutic molecules can act broadly on pathogenic T cells, including Th17 cells. Intravenous immunoglobulin (IVIg), a therapeutic preparation of normal $\lg \mathrm{G}$ obtained from pooled plasma of thousands of healthy donors, inhibits both differentiation and expansion of Th17 cells and suppresses Th17 cytokines IL-17A, IL-21, IL-22, and CCL20. ${ }^{109,110}$ This inhibition by IVIg was associated with suppression of both RORC and STAT3. The inhibition of Th17 expansion was associated with a reciprocal regulation of Tregs. ${ }^{109,110}$ These novel mechanisms of IVIg might explain its therapeutic efficacy in autoimmune diseases such as Kawasaki disease, dermatomyositis, and vasculitis, where Th17 cells play an important role in pathogenesis. ${ }^{111}$ By enhancing the affinity of GRs, IVIg might also overcome IL-17A-mediated steroid unresponsiveness or resistance. ${ }^{89,112}$ Rapamycin, an immunosuppressive drug, promotes the in vitro expansion of $n$ Tregs via the inhibition of effector $\mathrm{T}$ cells, including Th17 cells. ${ }^{113}$ These effects of rapamycin are mediated by the inhibition of the mTOR pathway.

\section{Conclusions and Perspectives}

Th17 cells display considerable plasticity. In addition to IL- $17^{+}$cells, Th17 cells with mixed phenotypes are observed in the peripheral blood and inflamed tissues. These findings imply that Th17 cells are unstable, and, depending on the type of inflammation and cytokine milieu, Th17 cells can acquire a phenotype of other T-cell subsets, such as $\mathrm{IL}-17^{+} \mathrm{IFN} \gamma^{+} \mathrm{T}$ cells and $\mathrm{IL} 17^{+} \mathrm{IL}-4^{+} \mathrm{T}$ cells. Based on more recent data obtained in IL-17A fate-reporter mice, ${ }^{56}$ Th17 cells appear to be stable under acute inflammation, whereas under chronic inflammation, these cells are vulnerable to obtain a mixed phenotype. Detailed investigations are required to confirm whether Th1-mediated or Th2-mediated autoimmune and inflammatory diseases are caused per se by Th1 or Th2 cells or by ex-Th17 cells that are converted into either Th1 or Th2 phenotype.

The instability of Th17 cells poses additional problems for isolating these cellular populations from the circulation and inflamed tissues. Although a combination of chemokine receptors and CD161 was used to isolate Th17 cells, it is not yet known whether these isolated cells are stable or whether this population contains a mixed population. Using CCR6, CCR4, CCR2, and CD161 markers as scaffolds, Th17 cell subsets can be classified further.

Several Th17-specific therapeutic strategies are under investigation. Although Th17 cells and their cytokines are associated with several autoimmune and inflammatory diseases, in most of these diseases, the pathogenic role of Th17 cells has not been formally demonstrated. Furthermore, other $\mathrm{CD} 4^{+} \mathrm{T}$-cell subsets have also been implicated in the pathogenesis of many of these Th17associated diseases, including psoriasis, IBD, SLE, and asthma. Therefore, in these diseases, therapies that target Th17 alone may not confer complete remission. Several therapeutic molecules that have shown encouraging results in experimental models have broader specificities and are promising candidates for clinical trials.

\section{Acknowledgment}

The authors acknowledge that numerous other key contributions were not cited because of space limitations.

\section{References}

1. Park $H$, Li Z, Yang $X O$, Chang $S H$, Nurieva R, Wang $Y H$, Wang $Y$, Hood L, Zhu Z, Tian Q, Dong C: A distinct lineage of CD4 T cells regulates tissue inflammation by producing interleukin 17. Nat Immunol 2005, 6:1133-1141

2. Veldhoen M, Hocking RJ, Atkins CJ, Locksley RM, Stockinger B: TGF- $\beta$ in the context of an inflammatory cytokine milieu supports de novo differentiation of IL-17-producing T cells. Immunity 2006, 24: 179-189

3. Bettelli E, Carrier Y, Gao W, Korn T, Strom TB, Oukka M, Weiner HL, Kuchroo VK: Reciprocal developmental pathways for the generation of pathogenic effector $\mathrm{TH} 17$ and regulatory T cells. Nature 2006, 441:235-238

4. Mangan PR, Harrington LE, O'Quinn DB, Helms WS, Bullard DC Elson CO, Hatton RD, Wahl SM, Schoeb TR, Weaver CT: Transforming growth factor-beta induces development of the $T(H) 17$ lineage. Nature 2006, 441:231-234

5. Acosta-Rodriguez EV, Rivino L, Geginat J, Jarrossay D, Gattorno M, Lanzavecchia A, Sallusto F, Napolitani G: Surface phenotype and antigenic specificity of human interleukin 17-producing $\mathrm{T}$ helper memory cells. Nat Immunol 2007, 8:639-646

6. Annunziato F, Cosmi L, Santarlasci V, Maggi L, Liotta F, Mazzinghi B, Parente E, Fili L, Ferri S, Frosali F, Giudici F, Romagnani P, Parronchi P, Tonelli F, Maggi E, Romagnani S: Phenotypic and functional features of human Th17 cells. J Exp Med 2007, 204:1849-1861

7. Sato W, Aranami T, Yamamura T: Cutting edge: human Th17 cells are identified as bearing CCR2+CCR5- phenotype. J Immunol 2007 , 178:7525-7529

8. Maggi L, Santarlasci V, Capone M, Peired A, Frosali F, Crome SQ, Querci V, Fambrini M, Liotta F, Levings MK, Maggi E, Cosmi L, Romagnani S, Annunziato F: CD161 is a marker of all human IL-17producing T-cell subsets and is induced by RORC. Eur $\mathrm{J}$ Immunol 2010, 40:2174-2181

9. Veldhoen M, Hocking RJ, Flavell RA, Stockinger B: Signals mediated by transforming growth factor-beta initiate autoimmune encephalomyelitis, but chronic inflammation is needed to sustain disease. Nat Immunol 2006, 7:1151-1156

10. Gutcher I, Donkor MK, Ma Q, Rudensky AY, Flavell RA, Li MO Autocrine transforming growth factor-beta1 promotes in vivo Th17 cell differentiation. Immunity 2011, 34:396-408

11. Korn T, Bettelli E, Gao W, Awasthi A, Jager A, Strom TB, Oukka M, Kuchroo VK: IL-21 initiates an alternative pathway to induce proinflammatory $T(H) 17$ cells. Nature 2007, 448:484-487

12. Nurieva R, Yang XO, Martinez G, Zhang Y, Panopoulos AD, Ma L, Schluns K, Tian Q, Watowich SS, Jetten AM, Dong C: Essential 
autocrine regulation by $\mathrm{IL}-21$ in the generation of inflammatory $\mathrm{T}$ cells. Nature 2007, 448:480-483

13. Zhou L, Ivanov II, Spolski R, Min R, Shenderov K, Egawa T, Levy DE, Leonard WJ, Littman DR: IL-6 programs $T(H)-17$ cell differentiation by promoting sequential engagement of the IL-21 and IL-23 pathways. Nat Immunol 2007, 8:967-974

14. Korn T, Bettelli E, Oukka M, Kuchroo VK: IL-17 and Th17 cells. Annu Rev Immunol 2009, 27:485-517

15. McGeachy MJ, Chen Y, Tato CM, Laurence A, Joyce-Shaikh B, Blumenschein WM, McClanahan TK, O'Shea JJ, Cua DJ: The interleukin 23 receptor is essential for the terminal differentiation of interleukin 17-producing effector T helper cells in vivo. Nat Immunol 2009, 10:314-324

16. Qin H, Wang L, Feng T, Elson CO, Niyongere SA, Lee SJ, Reynolds SL, Weaver CT, Roarty K, Serra R, Benveniste EN, Cong Y: TGF- $\beta$ promotes Th17 cell development through inhibition of SOCS3. J Immunol 2009, 183:97-105

17. Ghoreschi K, Laurence A, Yang XP, Tato CM, McGeachy MJ, Konkel JE, Ramos HL, Wei L, Davidson TS, Bouladoux N, Grainger JR, Chen Q, Kanno Y, Watford WT, Sun HW, Eberl G, Shevach EM, Belkaid Y, Cua DJ, Chen W, O'Shea JJ: Generation of pathogenic $\mathrm{T}(\mathrm{H}) 17$ cells in the absence of TGF- $\beta$ signalling. Nature 2010, 467: 967-971

18. Das J, Ren G, Zhang L, Roberts Al, Zhao X, Bothwell AL, Van Kaer $L$, Shi $Y$, Das G: Transforming growth factor $\beta$ is dispensable for the molecular orchestration of Th17 cell differentiation. J Exp Med 2009, 206:2407-2416

19. Acosta-Rodriguez EV, Napolitani G, Lanzavecchia A, Sallusto F: Interleukins $1 \beta$ and 6 but not transforming growth factor- $\beta$ are essential for the differentiation of interleukin 17-producing human $T$ helper cells. Nat Immunol 2007, 8:942-949

20. Wilson NJ, Boniface K, Chan JR, McKenzie BS, Blumenschein WM, Mattson JD, Basham B, Smith K, Chen T, Morel F, Lecron JC, Kastelein RA, Cua DJ, McClanahan TK, Bowman EP, de Waal Malefyt R: Development, cytokine profile and function of human interleukin 17-producing helper T cells. Nat Immunol 2007, 8:950-957

21. Yang L, Anderson DE, Baecher-Allan C, Hastings WD, Bettelli E, Oukka M, Kuchroo VK, Hafler DA: IL-21 and TGF- $\beta$ are required for differentiation of human $\mathrm{T}(\mathrm{H}) 17$ cells. Nature 2008, 454:350-352

22. Manel N, Unutmaz D, Littman DR: The differentiation of human $T(H)-17$ cells requires transforming growth factor- $\beta$ and induction of the nuclear receptor ROR $\gamma$ t. Nat Immunol 2008, 9:641-649

23. Volpe E, Servant N, Zollinger R, Bogiatzi SI, Hupe P, Barillot E, Soumelis $\mathrm{V}$ : A critical function for transforming growth factor- $\beta$, interleukin 23 and proinflammatory cytokines in driving and modulating human $T(H)-17$ responses. Nat Immunol 2008, 9:650-657

24. Cosmi L, De Palma R, Santarlasci V, Maggi L, Capone M, Frosali F, Rodolico G, Querci V, Abbate G, Angeli R, Berrino L, Fambrini M, Caproni M, Tonelli F, Lazzeri E, Parronchi P, Liotta F, Maggi E, Romagnani S, Annunziato F: Human interleukin 17-producing cells originate from a CD161+CD4+ T cell precursor. J Exp Med 2008, 205:1903-1916

25. Lee WW, Kang SW, Choi J, Lee SH, Shah K, Eynon EE, Flavell RA, Kang I: Regulating human Th17 cells via differential expression of IL-1 receptor. Blood 2010, 115:530-540

26. Santarlasci V, Maggi L, Capone M, Frosali F, Querci V, De Palma R, Liotta F, Cosmi L, Maggi E, Romagnani S, Annunziato F: TGF- $\beta$ indirectly favors the development of human Th17 cells by inhibiting Th1 cells. Eur J Immunol 2009, 39:207-215

27. Martinez GJ, Zhang Z, Reynolds JM, Tanaka S, Chung Y, Liu T, Robertson E, Lin X, Feng XH, Dong C: Smad2 positively regulates the generation of Th17 cells. J Biol Chem 2010, 285:29039-29043

28. Ichiyama K, Sekiya T, Inoue N, Tamiya T, Kashiwagi I, Kimura A, Morita R, Muto G, Shichita T, Takahashi R, Yoshimura A: Transcription factor Smad-independent $\mathrm{T}$ helper 17 cell induction by transforming-growth factor- $\beta$ is mediated by suppression of eomesodermin. Immunity 2011, 34:741-754

29. Wei L, Laurence A, Elias KM, O'Shea JJ: IL-21 is produced by Th17 cells and drives IL-17 production in a STAT3-dependent manner. J Biol Chem 2007, 282:34605-34610

30. Chen Z, Laurence A, Kanno Y, Pacher-Zavisin M, Zhu BM, Tato C, Yoshimura A, Hennighausen L, O'Shea JJ: Selective regulatory function of Socs3 in the formation of IL-17-secreting T cells, Proc Nat Acad Sci U S A 2006, 103:8137-8142
31. Chung Y, Chang SH, Martinez GJ, Yang XO, Nurieva R, Kang HS Ma L, Watowich SS, Jetten AM, Tian Q, Dong C: Critical regulation of early Th17 cell differentiation by interleukin-1 signaling. Immunity 2009, 30:576-587

32. Brustle A, Heink S, Huber M, Rosenplanter C, Stadelmann C, Yu P, Arpaia E, Mak TW, Kamradt T, Lohoff M: The development of inflammatory $T(H)-17$ cells requires interferon-regulatory factor 4 . Nat Immunol 2007, 8:958-966

33. Okamoto K, Iwai Y, Oh-Hora M, Yamamoto M, Morio T, Aoki K, Ohya $\mathrm{K}$, Jetten AM, Akira S, Muta T, Takayanagi $\mathrm{H}$ : $\mid \kappa \mathrm{B} \zeta$ regulates $\mathrm{T}(\mathrm{H}) 17$ development by cooperating with ROR nuclear receptors. Nature 2010, 464:1381-1385

34. Schraml BU, Hildner K, Ise W, Lee WL, Smith WA, Solomon B Sahota G. Sim J, Mukasa R, Cemerski S, Hatton RD, Stormo GD, Weaver CT, Russell JH, Murphy TL, Murphy KM: The AP-1 transcription factor Batf controls $\mathrm{T}(\mathrm{H}) 17$ differentiation. Nature 2009, 460 405-409

35. Zhang F, Meng G, Strober W: Interactions among the transcription factors Runx1. ROR $\gamma$ t and Foxp3 regulate the differentiation of in terleukin 17-producing T cells, Nat Immunol 2008, 9:1297-1306

36. Zhou L, Lopes JE, Chong MM, Ivanov II, Min R, Victora GD, Shen Y Du J, Rubtsov YP, Rudensky AY, Ziegler SF, Littman DR: TGF- $\beta$ induced Foxp3 inhibits $\mathrm{T}(\mathrm{H}) 17$ cell differentiation by antagonizing ROR $\gamma$ t function. Nature 2008, 453:236-240

37. Yang XO, Panopoulos AD, Nurieva R, Chang SH, Wang D, Watowich SS, Dong C: STAT3 regulates cytokine-mediated generation of inflammatory helper T cells. J Biol Chem 2007, 282:9358-9363

38. Laurence A, Tato CM, Davidson TS, Kanno Y, Chen Z, Yao Z, Blank RB, Meylan F, Siegel R, Hennighausen L, Shevach EM, O'Shea JJ: Interleukin-2 signaling via STAT5 constrains T helper 17 cell generation. Immunity 2007, 26:371-381

39. Moisan J, Grenningloh R, Bettelli E, Oukka M, Ho IC: Ets-1 is a negative regulator of Th17 differentiation. J Exp Med 2007, 204: 2825-2835

40. Liao W, Lin JX, Wang L, Li P, Leonard WJ: Modulation of cytokine receptors by $\mathrm{IL}-2$ broadly regulates differentiation into helper $\mathrm{T}$ cell lineages. Nat Immunol 2011, 12:551-559

41. Elias KM, Laurence A, Davidson TS, Stephens G, Kanno Y, Shevach EM, O'Shea JJ: Retinoic acid inhibits Th17 polarization and enhances FoxP3 expression through a Stat-3/Stat-5 independent signaling pathway. Blood 2008, 111:1013-1020

42. Mucida D, Park Y, Kim G, Turovskaya O, Scott I, Kronenberg M Cheroutre $\mathrm{H}$ : Reciprocal $\mathrm{TH} 17$ and regulatory $\mathrm{T}$ cell differentiation mediated by retinoic acid. Science 2007, 317:256-260

43. Quintana FJ, Basso AS, Iglesias AH, Korn T, Farez MF, Bettelli E, Caccamo M, Oukka M, Weiner HL: Control of T(reg) and $\mathrm{T}(\mathrm{H}) 17$ cell differentiation by the aryl hydrocarbon receptor. Nature 2008, 453 65-71

44. Veldhoen M, Hirota K, Westendorf AM, Buer J, Dumoutier L, Renauld JC, Stockinger B: The aryl hydrocarbon receptor links TH17-cellmediated autoimmunity to environmental toxins. Nature 2008, 453 106-109

45. Quintana FJ, Murugaiyan G, Farez MF, Mitsdoerffer M, Tukpah AM, Burns EJ, Weiner HL: An endogenous aryl hydrocarbon receptor ligand acts on dendritic cells and T cells to suppress experimental autoimmune encephalomyelitis, Proc Natl Acad Sci U S A 2010, 107:20768-20773

46. Gandhi R, Kumar D, Burns EJ, Nadeau M, Dake B, Laroni A, Kozoriz D, Weiner HL, Quintana FJ: Activation of the aryl hydrocarbon receptor induces human type 1 regulatory $T$ cell-like and Foxp3(+) regulatory T cells. Nat Immunol 2010, 11:846-853

47. Chen Y, Haines CJ, Gutcher I, Hochweller K, Blumenschein WM McClanahan T, Hammerling G, Li MO, Cua DJ, McGeachy MJ: Foxp3(+) regulatory T cells promote T helper 17 cell development in vivo through regulation of interleukin-2. Immunity 2011, 34:409-421

48. Pandiyan P, Conti HR, Zheng L, Peterson AC, Mathern DR, HernandezSantos N, Edgerton M, Gaffen SL, Lenardo MJ: CD4(+)CD25(+)Foxp3(+) regulatory $\mathrm{T}$ cells promote Th17 cells in vitro and enhance host resistance in mouse Candida albicans Th17 cell infection model. Immunity 2011, 34:422-434

49. Lazarevic V, Chen X, Shim JH, Hwang ES, Jang E, Bolm AN, Oukka M, Kuchroo VK, Glimcher LH: T-bet represses T(H)17 differentiation by preventing Runx1-mediated activation of the gene encoding ROR $\gamma$ t. Nat Immunol 2011, 12:96-104 
50. Batten M, Li J, Yi S, Kljavin NM, Danilenko DM, Lucas S, Lee J, de Sauvage FJ, Ghilardi N: Interleukin 27 limits autoimmune encephalomyelitis by suppressing the development of interleukin 17-producing T cells. Nat Immunol 2006, 7:929-936

51. Stumhofer JS, Silver JS, Laurence A, Porrett PM, Harris TH, Turka LA, Ernst M, Saris CJ, O'Shea JJ, Hunter CA: Interleukins 27 and 6 induce STAT3-mediated T cell production of interleukin 10. Nat Immunol 2007, 8:1363-1371

52. Fitzgerald DC, Zhang GX, El-Behi M, Fonseca-Kelly Z, Li H, Yu S, Saris CJ, Gran B, Ciric B, Rostami A: Suppression of autoimmune inflammation of the central nervous system by interleukin 10 secreted by interleukin 27-stimulated T cells. Nat Immunol 2007 , 8:1372-1379

53. van Hamburg JP, de Bruijn MJ, Ribeiro de Almeida C, van Zwam M, van Meurs M, de Haas E, Boon L, Samsom JN, Hendriks RW: Enforced expression of GATA3 allows differentiation of IL-17-producing cells, but constrains Th17-mediated pathology. Eur J Immunol 2008, 38:2573-2586

54. Voo KS, Wang YH, Santori FR, Boggiano C, Arima K, Bover L, Hanabuchi S, Khalili J, Marinova E, Zheng B, Littman DR, Liu YJ: Identification of IL-17-producing FOXP3+ regulatory $T$ cells in humans, Proc Natl Acad Sci U S A 2009, 106:4793-4798

55. Cosmi L, Maggi L, Santarlasci V, Capone M, Cardilicchia E, Frosali F, Querci V, Angeli R, Matucci A, Fambrini M, Liotta F, Parronchi P, Maggi E, Romagnani S, Annunziato F: Identification of a novel subset of human circulating memory CD4(+) T cells that produce both IL-17A and IL-4. J Allergy Clin Immunol 2010, 125:222-230, e221-224

56. Hirota K, Duarte JH, Veldhoen M, Hornsby E, Li Y, Cua DJ, Ahlfors $\mathrm{H}$, Wilhelm C, Tolaini M, Menzel U, Garefalaki A, Potocnik AJ, Stockinger B: Fate mapping of IL-17-producing $T$ cells in inflammatory responses. Nat Immunol 2011, 12:255-263

57. Lexberg $\mathrm{MH}$, Taubner A, Albrecht I, Lepenies I, Richter A, Kamradt T, Radbruch A, Chang HD: IFN- $\gamma$ and IL-12 synergize to convert in vivo generated Th17 into Th1/Th17 cells. Eur J Immunol 2010, 40: 3017-3027

58. Esplugues E, Huber S, Gagliani N, Hauser AE, Town T, Wan YY, O'Connor W Jr, Rongvaux A, Van Rooijen N, Haberman AM, Iwakura Y, Kuchroo VK, Kolls JK, Bluestone JA, Herold KC, Flavell RA: Control of TH17 cells occurs in the small intestine. Nature 2011, 475:514-518

59. Wei G, Wei L, Zhu J, Zang C, Hu-Li J, Yao Z, Cui K, Kanno Y, Roh TY, Watford WT, Schones DE, Peng W, Sun HW, Paul WE, O'Shea JJ, Zhao K: Global mapping of H3K4me3 and H3K27me3 reveals specificity and plasticity in lineage fate determination of differentiating CD4+ T cells. Immunity 2009, 30:155-167

60. Miossec $\mathrm{P}$, Korn T, Kuchroo VK: Interleukin-17 and type 17 helper T cells. N Engl J Med 2009, 361:888-898

61. Wilke CM, Bishop K, Fox D, Zou W: Deciphering the role of Th17 cells in human disease. Trends Immunol 2011, 32:603-611

62. Shen H, Goodall JC, Hill Gaston JS: Frequency and phenotype of peripheral blood Th17 cells in ankylosing spondylitis and rheumatoid arthritis. Arthritis Rheum 2009, 60:1647-1656

63. Lubberts E, Koenders MI, van den Berg WB: The role of T-cell interleukin-17 in conducting destructive arthritis: lessons from animal models. Arthritis Res Ther 2005, 7:29-37

64. Kwok SK, Cho ML, Park MK, Oh HJ, Park JS, Her YM, Lee SY, Youn J, Ju JH, Park KS, Kim SI, Kim HY, Park SH: Interleukin-21 promotes osteoclastogenesis in rheumatoid arthritis in humans and mice, $\mathrm{Ar}$ thritis Rheum 2012, 64:740-751

65. Young DA, Hegen M, Ma HL, Whitters MJ, Albert LM, Lowe L, Senices M, Wu PW, Sibley B, Leathurby Y, Brown TP, NickersonNutter C, Keith JC Jr, Collins M: Blockade of the interleukin-21/ interleukin-21 receptor pathway ameliorates disease in animal models of rheumatoid arthritis. Arthritis Rheum 2007, 56:1152-1163

66. Leipe J, Schramm MA, Grunke M, Baeuerle M, Dechant C, Nigg AP, Witt MN, Vielhauer V, Reindl CS, Schulze-Koops $H$, Skapenko A: Interleukin 22 serum levels are associated with radiographic progression in rheumatoid arthritis. Ann Rheum Dis 2011, 70:14531457

67. Marijnissen RJ, Koenders MI, Smeets RL, Stappers MH, NickersonNutter C, Joosten LA, Boots AM, van den Berg WB: Increased expression of interleukin-22 by synovial Th17 cells during late stages of murine experimental arthritis is controlled by interleukin-1 and enhances bone degradation. Arthritis Rheum 2011 63:2939-2948

68. Cosmi L, Cimaz R, Maggi L, Santarlasci V, Capone M, Borriello F, Frosali F, Querci V, Simonini G, Barra G, Piccinni MP, Liotta F, De Palma R, Maggi E, Romagnani S, Annunziato F: Evidence of the transient nature of the Th17 phenotype of CD4+CD161+ T cells in the synovial fluid of patients with juvenile idiopathic arthritis. Arthritis Rheum 2011, 63:2504-2515

69. Nistala K, Adams S, Cambrook H, Ursu S, Olivito B, de Jager W, Evans JG, Cimaz R, Bajaj-Elliott M, Wedderburn LR: Th17 plasticity in human autoimmune arthritis is driven by the inflammatory environment, Proc Natl Acad Sci U S A 2010, 107:14751-14756

70. Yang J, Chu Y, Yang X, Gao D, Zhu L, Wan L, Li M: Th17 and natural Treg cell population dynamics in systemic lupus erythematosus. Arthritis Rheum 2009, 60:1472-1483

71. Hsu HC, Yang P, Wang J, Wu Q, Myers R, Chen J, Yi J, Guentert T, Tousson A, Stanus AL, Le TV, Lorenz RG, Xu H, Kolls JK, Carter RH, Chaplin DD, Williams RW, Mountz JD: Interleukin 17-producing T helper cells and interleukin 17 orchestrate autoreactive germinal center development in autoimmune BXD2 mice. Nat Immunol 2008 9:166-175

72. Doreau A, Belot A, Bastid J, Riche B, Trescol-Biemont MC, Ranchin B, Fabien N, Cochat P, Pouteil-Noble C, Trolliet P, Durieu I, Tebib J, Kassai B, Ansieau S, Puisieux A, Eliaou JF, Bonnefoy-Berard N Interleukin 17 acts in synergy with B cell-activating factor to influence B cell biology and the pathophysiology of systemic lupus erythematosus. Nat Immunol 2009, 10:778-785

73. Sawalha AH, Kaufman KM, Kelly JA, Adler AJ, Aberle T, Kilpatrick J, Wakeland EK, Li QZ, Wandstrat AE, Karp DR, James JA, Merrill JT, Lipsky P, Harley JB: Genetic association of interleukin-21 polymorphisms with systemic lupus erythematosus. Ann Rheum Dis 2008, $67: 458-461$

74. Webb R, Merrill JT, Kelly JA, Sestak A, Kaufman KM, Langefeld CD, Ziegler J, Kimberly RP, Edberg JC, Ramsey-Goldman R, Petri M Reveille JD, Alarcon GS, Vila LM, Alarcon-Riquelme ME, James JA, Gilkeson GS, Jacob CO, Moser KL, Gaffney PM, Vyse TJ, Nath SK Lipsky P, Harley JB, Sawalha AH: A polymorphism within IL21P confers risk for systemic lupus erythematosus. Arthritis Rheum 2009, 60:2402-2407

75. Leng RX, Pan HF, Chen GM, Feng CC, Fan YG, Ye DQ, Li XP: The dual nature of Ets-1: focus to the pathogenesis of systemic lupus erythematosus. Autoimmun Rev 2011, 10:439-443

76. Herber D, Brown TP, Liang S, Young DA, Collins M, Dunussi-Joannopoulos K: IL-21 has a pathogenic role in a lupus-prone mouse model and its blockade with IL-21R. Fc reduces disease progression, J Immunol 2007, 178:3822-3830

77. Lock C, Hermans G, Pedotti R, Brendolan A, Schadt E, Garren H Langer-Gould A, Strober S, Cannella B, Allard J, Klonowski P, Austin A, Lad N, Kaminski N, Galli SJ, Oksenberg JR, Raine CS, Heller R Steinman L: Gene-microarray analysis of multiple sclerosis lesions yields new targets validated in autoimmune encephalomyelitis. Nat Med 2002, 8:500-508

78. Tzartos JS, Friese MA, Craner MJ, Palace J, Newcombe J, Esiri MM, Fugger L: Interleukin-17 production in central nervous system-infiltrating $T$ cells and glial cells is associated with active disease in multiple sclerosis. Am J Pathol 2008, 172:146-155

79. Carlson T, Kroenke M, Rao P, Lane TE, Segal B: The Th17-ELR+ CXC chemokine pathway is essential for the development of central nervous system autoimmune disease. J Exp Med 2008, 205:811-823

80. Komiyama Y, Nakae S, Matsuki T, Nambu A, Ishigame H, Kakuta S, Sudo K, Iwakura Y: IL-17 plays an important role in the development of experimental autoimmune encephalomyelitis. J Immunol 2006 , 177:566-573

81. Siffrin V, Radbruch $H$, Glumm R, Niesner R, Paterka M, Herz J Leuenberger T, Lehmann SM, Luenstedt S, Rinnenthal JL, Laube G, Luche $\mathrm{H}$, Lehnardt S, Fehling $\mathrm{HJ}$, Griesbeck O, Zipp F: In vivo imaging of partially reversible Th17 cell-induced neuronal dysfunction in the course of encephalomyelitis. Immunity 2010, 33:424-436

82. Codarri L, Gyulveszi G, Tosevski V, Hesske L, Fontana A, Magnenat $\mathrm{L}$, Suter T, Becher B: ROR $\gamma$ t drives production of the cytokine GM-CSF in helper T cells, which is essential for the effector phase of autoimmune neuroinflammation. Nat Immunol 2011, 12:560-567

83. El-Behi M, Ciric B, Dai H, Yan Y, Cullimore M, Safavi F, Zhang GX Dittel BN, Rostami A: The encephalitogenicity of $T(H) 17$ cells is 
dependent on IL-1- and IL-23-induced production of the cytokine GM-CSF. Nat Immunol 2011, 12:568-575

84. King IL, Kroenke MA, Segal BM: GM-CSF-dependent. CD103+ dermal dendritic cells play a critical role in Th effector cell differentiation after subcutaneous immunization, J Exp Med 2010, 207:953-961

85. Lowes MA, Kikuchi T, Fuentes-Duculan J, Cardinale I, Zaba LC, Haider AS, Bowman EP, Krueger JG: Psoriasis vulgaris lesions contain discrete populations of Th1 and Th17 T cells. J Invest Dermatol 2008, 128:1207-1211

86. Ma HL, Liang S, Li J, Napierata L, Brown T, Benoit S, Senices M, Gill D, Dunussi-Joannopoulos K, Collins M, Nickerson-Nutter C, Fouser LA, Young DA: IL-22 is required for Th17 cell-mediated pathology in a mouse model of psoriasis-like skin inflammation. J Clin Invest 2008, 118:597-607

87. Zenewicz LA, Antov A, Flavell RA: CD4 T-cell differentiation and inflammatory bowel disease. Trends Mol Med 2009, 15:199-207

88. Zenewicz LA, Yancopoulos GD, Valenzuela DM, Murphy AJ, Stevens S, Flavell RA: Innate and adaptive interleukin-22 protects mice from inflammatory bowel disease. Immunity 2008, 29:947-957

89. van den Berg WB, Miossec P: IL-17 as a future therapeutic target for rheumatoid arthritis. Nat Rev Rheumatol 2009, 5:549-553

90. Milovanovic M, Drozdenko G, Weise C, Babina M, Worm M: Interleukin-17A promotes IgE production in human B cells. J Invest Dermatol 2010, 130:2621-2628

91. Bayry J, Thirion M, Delignat S, Misra N, Lacroix-Desmazes S, Kazatchkine MD, Kaveri SV: Dendritic cells and autoimmunity. Autoimmun Rev 2004, 3:183-187

92. Bayry J, Lacroix-Desmazes S, Kazatchkine MD, Kaveri SV: Monoclonal antibody and intravenous immunoglobulin therapy for rheumatic diseases: rationale and mechanisms of action. Nat Clin Pract Rheumatol 2007, 3:262-272

93. Andre S, Tough DF, Lacroix-Desmazes S, Kaveri SV, Bayry J: Surveillance of antigen-presenting cells by $C D 4+C D 25+$ regulatory $T$ cells in autoimmunity: immunopathogenesis and therapeutic implications. Am J Pathol 2009, 174:1575-1587

94. Bayry J, Siberil S, Triebel F, Tough DF, Kaveri SV: Rescuing $\mathrm{CD} 4+\mathrm{CD} 25+$ regulatory T-cell functions in rheumatoid arthritis by cytokine-targeted monoclonal antibody therapy. Drug Discov Today 2007, 12:548-552

95. Klemann C, Raveney BJ, Klemann AK, Ozawa T, von Horsten S, Shudo K, Oki S, Yamamura T: Synthetic retinoid AM80 inhibits Th17 cells and ameliorates experimental autoimmune encephalomyelitis. Am J Pathol 2009, 174:2234-2245

96. Sundrud MS, Koralov SB, Feuerer M, Calado DP, Kozhaya AE, Rhule-Smith A, Lefebvre RE, Unutmaz D, Mazitschek R, Waldner $\mathrm{H}$, Whitman M, Keller T, Rao A: Halofuginone inhibits TH17 cell differentiation by activating the amino acid starvation response. Science 2009, 324:1334-1338

97. Krueger GG, Langley RG, Leonardi C, Yeilding N, Guzzo C, Wang Y, Dooley LT, Lebwohl M: A human interleukin-12/23 monoclonal antibody for the treatment of psoriasis. N Engl J Med 2007, 356:580-592

98. Sandborn WJ, Feagan BG, Fedorak RN, Scherl E, Fleisher MR, Katz $\mathrm{S}$, Johanns J, Blank M, Rutgeerts P: A randomized trial of Ustekinumab, a human interleukin-12/23 monoclonal antibody, in patients with moderate-to-severe Crohn's disease. Gastroenterology 2008, 135:1130-1141

99. Joshi S, Pantalena LC, Liu XK, Gaffen SL, Liu H, Rohowsky-Kochan C, Ichiyama K, Yoshimura A, Steinman L, Christakos S, Youssef S: 1,25-dihydroxyvitamin $D(3)$ ameliorates Th17 autoimmunity via transcriptional modulation of interleukin-17A. Mol Cell Biol 2011, 31: 3653-3669
100. Grigorian A, Araujo L, Naidu NN, Place D, Choudhury B, Demetriou M: N-acetylglucosamine inhibits T-helper 1 (Th1)/T-helper 17 (Th17) responses and treats experimental autoimmune encephalomyelitis. J Biol Chem 2011, 286:40133-40141

101. Hueber W, Patel DD, Dryja T, Wright AM, Koroleva I, Bruin G, Antoni C, Draelos Z, Gold MH, Durez P, Tak PP, Gomez-Reino JJ, Foster CS, Kim RY, Samson CM, Falk NS, Chu DS, Callanan D, Nguyen QD, Rose K, Haider A, Di Padova F: Effects of AIN457, a fully human antibody to interleukin-17A, on psoriasis, rheumatoid arthritis, and uveitis. Sci Transl Med 2010, 52ra722:

102. Genovese MC, Van den Bosch F, Roberson SA, Bojin S, Biagini IM, Ryan P, Sloan-Lancaster J: LY2439821, a humanized anti-interleukin-17 monoclonal antibody, in the treatment of patients with rheumatoid arthritis: a phase I randomized, double-blind, placebo-controlled, proof-of-concept study. Arthritis Rheum 2010, 62:929-939

103. Klotz L, Burgdorf S, Dani I, Saijo K, Flossdorf J, Hucke S, Alferink J, Nowak N, Beyer M, Mayer G, Langhans B, Klockgether T, Waisman A, Eberl G, Schultze J, Famulok M, Kolanus W, Glass C, Kurts C Knolle PA: The nuclear receptor PPAR $\gamma$ selectively inhibits Th17 differentiation in a T cell-intrinsic fashion and suppresses CNS autoimmunity. J Exp Med 2009, 206:2079-2089

104. Zhang X, Jin J, Peng X, Ramgolam VS, Markovic-Plese S: Simvastatin inhibits IL-17 secretion by targeting multiple IL-17-regulatory cytokines and by inhibiting the expression of $\mathrm{IL}-17$ transcription factor RORC in CD4+ lymphocytes. J Immunol 2008, 180:69886996

105. Huh JR, Leung MW, Huang P, Ryan DA, Krout MR, Malapaka RR, Chow J, Manel N, Ciofani M, Kim SV, Cuesta A, Santori FR, Lafaille JJ, Xu HE, Gin DY, Rastinejad F, Littman DR: Digoxin and its derivatives suppress $\mathrm{TH} 17$ cell differentiation by antagonizing ROR $\gamma \mathrm{t}$ activity. Nature 2011, 472:486-490

106. Kitabayashi C, Fukada T, Kanamoto M, Ohashi W, Hojyo S, Atsumi T, Ueda N, Azuma I, Hirota H, Murakami M, Hirano T: Zinc suppresses Th17 development via inhibition of STAT3 activation. Int Immunol 2010, 22:375-386

107. Singh TP, Huettner B, Koefeler H, Mayer G, Bambach I, Wallbrecht $\mathrm{K}$, Schon MP, Wolf P: Platelet-activating factor blockade inhibits the T-helper type 17 cell pathway and suppresses psoriasis-like skin disease in K5.hTGF- $\beta 1$ transgenic mice. Am J Pathol 2011, 178 699-708

108. Cao W, Yang Y, Wang Z, Liu A, Fang L, Wu F, Hong J, Shi Y, Leung S, Dong C, Zhang JZ: Leukemia inhibitory factor inhibits T helper 17 cell differentiation and confers treatment effects of neural progenitor cell therapy in autoimmune disease. Immunity 2011, 35:273-284

109. Maddur MS, Vani J, Hegde P, Lacroix-Desmazes S, Kaveri SV, Bayry J: Inhibition of differentiation, amplification, and function of human TH17 cells by intravenous immunoglobulin, J Allergy Clin Immunol 2011, 127:823-830, e821-827

110. Maddur MS, Kaveri SV, Bayry J: Comparison of different IVIg preparations on IL-17 production by human Th17 cells. Autoimmun Rev 2011, 10:809-810

111. Bayry J, Negi VS, Kaveri SV: Intravenous immunoglobulin therapy in rheumatic diseases. Nat Rev Rheumatol 2011, 7:349-359

112. Pashov A, Delignat S, Bayry J, Kaveri SV: Enhancement of the affinity of glucocorticoid receptors as a mechanism underlying the steroid-sparing effect of intravenous immunoglobulin. J Rheumatol 2011, 38:2275

113. Kopf H, de la Rosa GM, Howard OM, Chen X: Rapamycin inhibits differentiation of Th17 cells and promotes generation of FoxP3+ T regulatory cells. Int Immunopharmacol 2007, 7:1819-1824 